\title{
Multidisciplinary teams: perceptions of professionals and oncological patients
}

\author{
(iDHugo Tanaka' \\ iD Gabriela Medeiros ${ }^{2}$ \\ (iD) Auro Giglio ${ }^{3}$
}

\begin{abstract}
1. Mestrado em Medicina - Médico Residente do Departamento de Hematologia e Oncologia da Faculdade de Medicina do ABC, Santo André, SP, Brasil. 2. Doutoranda em Engenharia Agrícola - Departamento do Centro de Ciências Biológicas e da Saúde, Unioeste, Cascavel, PR, Brasil.
\end{abstract} 3. Professor Titular do Departamento de Hematologia e Oncologia da Faculdade de Medicina do ABC, Santo André, SP, Brasil.

http://dx.doi.org/10.1590/1806-9282.66.4.419

\begin{abstract}
SUMMARY
Multidisciplinary teams are increasingly employed to treat cancer patients. This study aimed to evaluate the perception of physicians, other health care professionals, and hospitalized oncological patients regarding the multidisciplinary teams of the public and private sector. In total, 18 doctors were interviewed; 63 health professionals and 120 cancer patients. Satisfaction with the work of the multidisciplinary team was positive among patients and physicians (averages of $89.4 \%$ and $66.82 \%$ respectively), but higher among patients ( $p$ <.0001), among women rather than men (averages of $77.5 \%$ and $85.21 \%$ respectively, $p<0.0001$ ), elderly individuals in comparison with adults (averages of $91.98 \%$ and $76.01 \%$ respectively, $p<0.0001$ ), and in the public sector in comparison with the private sector (averages of 83.12 and 70.74 respectively, $p<0.0001$ ). The results demonstrate that despite the difference between groups, patients and members of multidisciplinary groups were satisfied with multidisciplinary care, and some groups, such as elderly women from public services, may especially benefit from multi-professional groups.
\end{abstract}

KEYWORDS: Patient care team. Integrality in Health. Medical Oncology.

\section{INTRODUCTION}

The current health care model has proven unable to explain and respond to the population's health and disease processes ${ }^{1}$. Thus, the current General Work Program has prioritized strategies to ensure healthy living and promote general well-being, aiming to achieve universal health coverage ${ }^{2}$. In this strategy, practices should not be limited to the disease but take into account historical-cultural factors ${ }^{3}$.

In the search for promoting the health of cancer patients, a multidisciplinary team of professionals, consisting of doctors, nurses, physical therapists, nutritionists, speech therapists and/or occupational therapists interact with a common goal. The coordination, communication, and decision-making between the members of the health team and patients undergoing cancer treatment can be improved when this type of approach is exploited ${ }^{4}$. However, since the concept of a multidisciplinary team is relatively new, there is no clear definition of its format ${ }^{5}$. Patient satisfaction has been shown to be positive when the teamwork is organized, multidisciplinary, agile, and efficient in care $^{6}$. In this context, communication is extremely relevant in the therapeutic relationship between the team and the patient and aims to provide trust so that an effective assistance relationship can be achieved ${ }^{7}$. 
Among healthcare systems worldwide, the Single Health System (SUS) is one of the greatest public ones; it is universal and the only one to ensure full assistance that is completely free ${ }^{8}$. However, the system presents major structural problems that hinder health promotion'. Such problems make SUS, which was conceived as a free and universal system, in, reality, a public system ${ }^{10}$.

There are public and private policies that determine the procedures and processes to be offered for cancer patients during their treatment and follow-up. One of the more complex processes in the care of cancer patients is a multidisciplinary approach. This work evaluated the satisfaction of patients and health professionals involved in multidisciplinary teams both in the private and public sectors.

\section{METHODS}

From June 2017 to July 2018, the perception of patients and healthcare professionals was evaluated through a questionnaire regarding their multidisciplinary activities in the period of cancer patient hospitalization. The patients selected were diagnosed with some type of neoplasia (lung, sarcoma, central nervous system, digestive tract, head and neck, hematological, gynecological, urological, colorectal or hidden), hospitalized for 24 hours or more in one of the following public or private hospitals in the state of São Paulo: Hospital de Ensino Padre Anchieta (public), Hospital Estadual Mario Covas (public), Hospital Alemão Oswaldo Cruz (private), and Instituto Brasileiro de Controle ao Câncer (private), and were followed-up by a multidisciplinary team (physicians, nurses, pharmacists, physical therapists, speech therapists, nutritionists, psychologists, and social workers)

Each member of the multidisciplinary team responded to a questionnaire containing eight questions to evaluate the perception of communication between the members of the multidisciplinary team, the benefits of multidisciplinary meetings, the work dynamics, and the interaction between different health professionals during the treatments. Oncologic patients also received a questionnaire with eight questions that sought to evaluate the patient's perception regarding the respect and concern of the multidisciplinary team with their health status, and if they were informed about their health condition and the possible treatments. The questions on satisfaction and dissatisfaction were to be answered with a "yes" or "no", and the level of acceptance was calculated per individual in percentages.

The normality of the samples was tested using the Kolmogorov-Smirnoff test. The quantitative variables with non-normal distribution were tested using the Mann-Whitney test, and categorical variables were analyzed by the chi-square test. The comparison between the level of acceptance of each group assessed and the categorical variables of gender, age (adult or elderly), and type of assistance (public or private) were analyzed by one-way ANOVA. All analyzes were performed using the R software.

\section{RESULTS}

We included 81 members of multidisciplinary teams (18 of the medical team, eight of the nursing team, 21 pharmacists, two physical therapists, 11 speech therapists, 17 nutritionists, two psychologists, and two social workers), composed exclusively by adult individuals ( $87.7 \%$ men and $17.2 \%$ women). We evaluated 120 patients (52.5\% men, 47.5\% women; $55.8 \%$ adults and $44.2 \%$ elderly), with different types of neoplasm (lung [10], sarcoma [3], central nervous system [5], digestive tract [11], head and neck [10], hematological [18], gynecological [17], urological [15], colorectal [10], hidden [2]), and only $5.8 \%$ of the patients were treated in the private service, against $94.2 \%$ in the public service. We observed significant differences in gender and age between members of the multidisciplinary team and the group of patients $\left(\mathrm{Chi}^{2}=19.32 ; \mathrm{p}<0.001 ; \mathrm{Chi}^{2}=48.58 ; \mathrm{p} \leq 0.001\right)$ (Table 1).

We observed greater satisfaction with multidisciplinary care among the patients than among the members of the multidisciplinary team (averages of $89.4 \%$ and $66.82 \%$, respectively, $\mathrm{F}=96.726, \mathrm{p} \leq 0.001$ ); among women than among men (mean of $77.5 \%$ and $85.21 \%$, respectively, $\mathrm{F}=7.5697, \mathrm{p} \leq 0.001$ ); among elderly people than adults (average of $91.98 \%$ and $76.01 \%$, respectively, $\mathrm{F}=30.668, \mathrm{p} \leq 0.001$ ); and in public than private care (average of $83.12 \%$ and $70.74 \%$, respectively, $\mathrm{F}=15.896, \mathrm{p} \leq 0.001)$. We did not observe significant differences in satisfaction among patients according to their types of neoplasia and staging (Diagnosis: $\mathrm{F}=0.87188, \mathrm{p}=0.56168$, Staging: $\mathrm{F}=0.74794, \mathrm{p}=0.58925)$.

\section{DISCUSSION}

The optimal medical management includes discussions about the status of the disease and treatment 
plan $^{11,12}$. Communication between the patients and the team is essential to ensure that these discussions are fruitful for the patients ${ }^{13}$. In this study, the patients showed a high level of satisfaction with the multidisciplinary team, which may reflect a good understanding of their individual therapeutic plan. In the literature, important factors of patient perception include empathy, the provision of hope, and active listening for effective communication with the patient ${ }^{14}$.

The satisfaction of physicians in relation to the multidisciplinary team was lower than that of patients, but still positive (66.82\%), which may reflect good communication within the team. We noticed that among the experts there is greater recognition of the importance of the multidisciplinary team and of communication as an essential element in patient care and for families under palliative care ${ }^{15,16}$. However, studies show that doctors believe that, in the context of a multidisciplinary approach, more precise information is provided to patients, but, despite that, interestingly, they do not show a clear preference for a multidisciplinary environment ${ }^{17}$. Therefore, the unclear preference for participation in multidisciplinary teams should be further investigated. Perhaps the participation in multidisciplinary teams requires additional time and effort from its members, which could hinder its more widespread acceptance by health professionals.

The patients who showed greater satisfaction with the multidisciplinary team were female, elderly, and treated by public services. Between genders, female patients with cancer are more prone to suffer from psychosocial problems $^{18}$, which could explain the perception of greater satisfaction among female patients due to the attention they receive from the multidisciplinary team. As to the level of acceptance among the elderly, evidence of interest and concern by the professionals are aspects that increase satisfaction ${ }^{19,20}$.

There is a significant association of care provided by the Unified Health System (SUS) with some demographic profiles, such as the predominance of women, children, black and brown patients, low schooling, and income $^{21}$. In relation to patients' satisfaction with the multidisciplinary team in connection with the type of health care system, patients from the public sector presented the greatest satisfaction. In relation to the members of the multidisciplinary team, studies

TABLE 1. SOCIODEMOGRAPHIC CHARACTERISTICS AND ACCEPTANCE BYTHE MULTIDISCIPLINARY TEAM AND GROUP OF PATIENTS

\begin{tabular}{|c|c|c|c|c|c|}
\hline Characteristics & $\begin{array}{l}\text { Multidisciplinary team } \\
\mathrm{N}=81\end{array}$ & $\begin{array}{l}\text { Patients } \\
\mathrm{N}=120\end{array}$ & Test & \multicolumn{2}{|c|}{ p-value } \\
\hline \multirow{2}{*}{$\begin{array}{l}\text { Gender } \\
N(\%)\end{array}$} & Male & $67(82.7)$ & $63(52.5)$ & \multirow{2}{*}{$19.32^{a}$} & \multirow[t]{2}{*}{$0.001^{*}$} \\
\hline & Female & $14(17.2)$ & $57(47.5)$ & & \\
\hline \multirow{2}{*}{$\begin{array}{l}\text { Care } \\
N(\%)\end{array}$} & Private & $40(49.3)$ & $7(5.8)$ & \multirow[t]{2}{*}{$51.19^{a}$} & \multirow[t]{2}{*}{$0.001^{*}$} \\
\hline & Public & $41(50.6)$ & $113(94.2)$ & & \\
\hline \multirow{2}{*}{$\begin{array}{l}\text { Age group } \\
N(\%)\end{array}$} & Adult & $81(100)$ & $67(55.8)$ & \multirow[t]{2}{*}{$48.58^{a}$} & \multirow[t]{2}{*}{$0.001^{*}$} \\
\hline & Elderly & $\mathrm{O}(0)$ & $53(44.2)$ & & \\
\hline \multirow[t]{2}{*}{ Level of approval } & Good & 66.82 & 89.27 & $-8.91^{B}$ & $0.001^{*}$ \\
\hline & Bad & 31.79 & 10.63 & & \\
\hline \multicolumn{6}{|c|}{ Good level of approval - Team } \\
\hline \multirow[t]{2}{*}{ Age } & Adult & 66.82 & $\mathrm{NE}$ & \multirow[t]{2}{*}{ NE } & \multirow[t]{2}{*}{ NE } \\
\hline & Elderly & - & NA & & \\
\hline \multirow[t]{2}{*}{ Care } & Public & 67.99 & $\mathrm{NE}$ & \multirow[t]{2}{*}{$0.798^{C}$} & \multirow[t]{2}{*}{0.374} \\
\hline & Private & 65.63 & NE & & \\
\hline \multirow[t]{2}{*}{ Gender } & Male & 66.60 & NE & \multirow{2}{*}{$0.127^{c}$} & \multirow[t]{2}{*}{0.722} \\
\hline & Female & 67.86 & NE & & \\
\hline \multicolumn{6}{|c|}{ Good level of approval - Patient } \\
\hline \multirow[t]{2}{*}{ Age } & Adult & NA & 91.98 & \multirow[t]{2}{*}{$2.15^{\mathrm{C}}$} & \multirow[t]{2}{*}{0.145} \\
\hline & Elderly & NA & 87.13 & & \\
\hline \multirow[t]{2}{*}{ Care } & Public & NA & 100 & \multirow[t]{2}{*}{$2.65^{c}$} & \multirow[t]{2}{*}{0.106} \\
\hline & Private & NA & 88.61 & & \\
\hline \multirow[t]{2}{*}{ Gender } & Male & NA & 89.09 & \multirow[t]{2}{*}{$0.014^{c}$} & \multirow[t]{2}{*}{0.907} \\
\hline & Female & NA & 89.47 & & \\
\hline
\end{tabular}

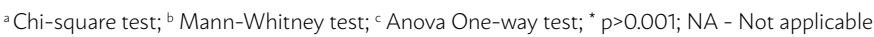


have shown that professionals who work in SUS have professional satisfaction regarding their relationships with patients and colleagues, but may be dissatisfied with the environment and work conditions, agility in examinations and measurements, among other things ${ }^{22}$. Probably, the satisfaction among patients cared by SUS may reflect greater attention received by each patient, considering the sum of visits from each team professional in a context of assistance to a larger number of patients.

The introduction of a multidisciplinary team is an important factor to improve survival rates ${ }^{23,24}$. Studies on the perception of patients and multidisciplinary teams can promote a reflection on actions to improve their functioning and care itself, as was the case, for example in the United Kingdom, where, after changes in the work plan, there was extremely high satisfaction among patients $(94 \%)^{5}$.

\section{CONCLUSION}

This study demonstrates a positive perception from cancer patients and the medical staff in relation to multidisciplinary teams, including factors that can interfere in perception, such as gender, age, and type of care (public and private). Elderly women who were assisted by public services seem to be the ones who derive more satisfaction from this approach.

\section{RESUMO}

Equipes multidisciplinares têm sido cada vez mais empregadas no tratamento de pacientes com câncer. Este estudo buscou avaliar a percepção de médicos, profissionais e pacientes oncológicos internados em relação à sua interação com a equipe multidisciplinar tanto no setor público quanto no privado. Entrevistamos 18 médicos, 63 profissionais da área da saúde e 120 pacientes oncológicos. Em relação ao trabalho da equipe multidisciplinar, a percepção foi positiva entre os pacientes e os médicos (médias iguais a 89,4\% e 66,82\%, respectivamente), mas maior entre os pacientes ( $p<0,001$ ), maior entre as pacientes mulheres do que entre os homens (médias de $77,5 \%$ e 85,21\%, respectivamente, $p<0,001$ ), maior entre os idosos do que entre os adultos (médias de 91,98\% e 76,01\%, respectivamente, p<0,0001), e maior no setor público do que no setor privado (médias de 83,12\% e 70,74\%, respectivamente, $p<0,0001$ ). Os resultados demonstram que apesar da diferença entre grupos, tanto pacientes como membros dos grupos multidisciplinares apresentaram satisfação com o atendimento multidisciplinar, e alguns grupos, como mulheres idosas cuidadas em serviços públicos, poderão especialmente ter um impacto maior de grupo multiprofissionais.

PALAVRAS-CHAVE: Equipe de assistência ao paciente. Integralidade em saúde. Oncologia.

\section{REFERENCES}

1. World Health Organization. Cuidados inovadores para condições crônicas: componentes estruturais de ação. Genève: Organização Mundial da Saúde; World Health Organization; 2002. Available from: http://www.saudedireta. com.br/docsupload/1334798934Cuidados inovadores parte_001.pdf

2. World Health Organization. Thirteenth General Programme of Work. 20192023. [cited 2019 Sept 04]. Available from: https://www.who.int/about/ what-we-do/thirteenth-general-programme-of-work-2019---2023

3. Vecchia MD, Martins ST. The concept of mental care of a family health team from a historical-cultural perspective. Cie Saude Colet. 2009;14(1):183-93.

4. Scarberry K, Ponsky L, Cherullo E, Larchian W, Bodner D, Cooney M, et al. Evaluating the impact of the genitourinary multidisciplinary tumour board: Should every cancer patient be discussed as standard of care? Can Urol Assoc J. 2018. doi: 10.5489/cuaj.5150.

5. Prades |, Remue E, van Hoof E, Borras IM. Is it worth reorganising cancer services on the basis of multidisciplinary teams (MDTs)? A systematic review of the objectives and organisation of MDTs and their impact on patient outcomes. Health Policy. 2015;119(4):464-74.

6. Bjegovich-Weidman M, Haid M, Kumar S, Huibregtse C, McDonald I, Krishnan S. Establishing a community-based lung cancer multidisciplinary clinic as part of a large integrated health care system: aurora health care. j Oncol Pract. 2010;6(6):e27-30.

7. Stub T, Quandt SA, Arcury TA, Sandberg JC, Kristoffersen AE. Complementary and conventional providers in cancer care: experience of communication with patients and steps to improve communication with other providers. BMC Complement Altern Med. 2017;17(1):301.
8. Ministério da Saúde. O sistema público de saúde brasileiro. Brasília: Ministério da Saúde; 2002. 45p. [cited 2019 Sept 04]. Available from: https://bvsms.saude.gov.br/bvs/publicacoes/sistema_saude.pdf

9. Miranda GMD, Mendes ACG, Silva ALA. O desafio da organização do Sistema Único de Saúde universal e resolutivo no pacto federativo brasileiro. Saúde Soc. 2017;26(2):329-35.

10. Mendes EV. 25 anos do Sistema Único de Saúde: resultados e desafios. Estud Av. 2013;27(78):27-34.

11. Hack TF, Degner LF, Parker PA; SCRN Communication Team. The communication goals and needs of cancer patients: a review. Psychooncology. 2005;14(10):831-45

12. Snelgrove RC, Subendran |, /haveri $K$, Thipphavong S, Cummings B, Brierley J, et al. Effect of multidisciplinary cancer conference on treatment plan for patients with primary rectal cancer. Dis Colon Rectum. 2015;58(7):653-8.

13. Datta SS, Tripathi L, Varghese R, Logan J, Gessler S, Chatterjee S, et al. Pivotal role of families in doctor-patient communication in oncology: a qualitative study of patients, their relatives and cancer clinicians. Eur J Cancer Care (Engl). 2017;26(5). doi: 10.1111/ecc.12543.

14. Bianchini D, Romeiro FB, Peuker AC, Castro EK. A comunicação profissional-paciente em oncologia: uma compreensão psicanalítica. Rev Bras Psicoter. 2016;18(2):20-36.

15. Catt $S$, Fallowfield $L$, Jenkins $V$, Langridge $C$, Cox $A$. The informational roles and psychological health of members of 10 oncology multidisciplinary teams in the UK. Br J Cancer. 2005;93(10):1092-7. 
16. Gandini RC, Martins MCF, Ribeiro MP, Santos DTG. Inventário de Depressão de Beck - BDI: validação fatorial para mulheres com câncer. Psico-USF. 2007;12(1):23-31.

17. Bellardita L, Donegani S, Spatuzzi AL, Valdagni R. Multidisciplinary versus one-on-one setting: a qualitative study of clinicians' perceptions of their relationship with patients with prostate cancer. J Oncol Pract. 2011;7(1):e1-5.

18. Koyama A, Matsuoka H, Ohtake Y, Makimura C, Sakai K, Sakamoto R, et al. Gender differences in cancer-related distress in Japan: a retrospective observation study. Biopsychosoc Med. 2016;10:10. doi: 10.1186/ s13030-016-0062-8.

19. Cardozo RN. An experimental study of customer effort, expectation, and satisfaction. J Mark Res. 1965;2(3):244-9

20. Rai A, Han X, Zheng Z, Yabroff KR, Jemal A. Determinants and outcomes of satisfaction with healthcare provider communication among cancer survivors. I Natl Compr Cancer Netw. 2018;16(8):975-84.
21. Fernandes MA, Evangelista CB, Platel IC, Agra G, Lopes MS, Rodrigues FA. The perception by nurses of the significance of palliative care in patients with terminal cancer. Cien Saude Colet. 2013;18(9):2589-96.

22. Ribeiro MCSA, Barata RB, Almeida MF, Silva ZP. Perfil sociodemográfico e padrão de utilização de serviços de saúde para usuários e não-usuários do SUS - PNAD 2003. Cien Saude Colet. 2006;11(4):1011-22.

23. Bordignon M, Monteiro MI, Mai S, Martins MFSV, Rech CRA, Trindade LL. Satisfação e insatisfação no trabalho de profissionais de enfermagem da oncologia do Brasil e Portugal. Texto Context - Enferm. 2015;24(4):925-33.

24. Stone E, Rankin N, Kerr S, Fong K, Currow DC, Phillips |, et al. Does presentation at multidisciplinary team meetings improve lung cancer survival? Findings from a consecutive cohort study. Lung Cancer. 2018;124:199-204. 